\title{
THE DEATH OF LAW: ANOTHER OBITUARY
}

\author{
WILLIAM LUCY*
}

ABSTRACT. This essay argues that a defining characteristic of modern law - the distinctive way in which it judges its addressees - will disappear. After sketching the distinctive nature of modern law's judgment, I show that it is part of a broader regulatory paradigm (rule or East Coast regulation) which is itself being superseded. Technological management is the alternative regulatory paradigm and I examine its rise and salience, showing how it might, in combination with the advent of ubiquitous computing, machine learning and artificial intelligence, cure a range of alleged pathologies that mark contemporary legal systems. The essay also demonstrates why technological management is now our regulatory default, its salience flowing from changes in the nature of our thinking about, and deployment of, power. The essay combines the work of Roger Brownsword, a leading contemporary jurist of technological management, with that of the world-renowned social theorist Michel Foucault.

KEYWORDS: judgment, regulation, technological management, governmentality.

The domain of law is set to shrink. (R. Brownsword, "Law as a Moral Judgment, the Domain of Jurisprudence, and Technological Regulation" in P. Capps and S.D. Pattinson (eds.), Ethical Rationalism and the Law (Oxford 2017), ch. 7, 130)

One day humanity will play with law just as children play with disused objects, not in order to restore them to their canonical use but to free them from it for good. (G. Agamben, State of Exception (Chicago 2005), 64)

\section{INTRODUCTION}

History teems with failed predictions. Two favourites are, first, the claim that every American household would have a nuclear-powered vacuum cleaner and, second, that the automobile would never supersede the

* Address for Correspondence: Law School, Durham University. Email: w.n.lucy@durham.ac.uk. Thanks to Philip Bennet, Roger Brownsword, Peter Cane, Johanna Jacques, Henry Jones, John Murphy, Shaun Pattinson, the CLJ editors and referees for thoughts and suggestions. 
horse. ${ }^{1}$ Some 66 years after the first prediction, nuclear-powered vacuums are, thankfully, vanishingly rare. One hundred and eighteen years on from the second, the good news is that horses still exist, although few commuters in the developed world can use them as a regular mode of travel. Making predictions is evidently a risky business, but in this essay I venture into that hazardous field. I predict that law, particularly the distinctive mode of judgment that modern law embodies, will die. ${ }^{2}$ Further, I suggest it will expire some time before 2061. These predictions raise at least three questions. First: what exactly is going to die? Second: why? And, third, will this death be a cause for regret? I answer these three questions in the following four sections of this essay, although I spend most time dealing with the first and second.

\section{LAW'S JUDGMENT}

I begin with a defining characteristic of modern law so deeply embedded in legal doctrine as to be barely noticeable by contemporary lawyers. ${ }^{3}$ It is the way modern law views its addressees and judges them. This is one of the most fundamental differences between feudal and modern legality and, in the common law world, it is captured in microcosm in courthouse iconography, through the image of Justitia. She holds scales and a sword and is often blindfolded because, of course, modern legality is blind. But not quite. For when we, the addressees of the law, stand in court facing judgment, or read the copious and complex body of juristic "do's and don'ts" we find in statutes, judicial decisions and legal textbooks, one thing is clear: the law is not interested in every aspect of our character, conduct and context.

So, in English tort law, what matters about my conduct as a defendant in a negligence action is whether it reached the standard of a reasonably competent performer: a reasonably competent driver, surgeon, lawyer or the like. I cannot defend myself in such an action by showing that, when I crashed into you, my driving was impaired because I was in the middle of a divorce, had flu and had slept badly. Nor can I exculpate myself by showing that I'm a bad driver only occasionally capable of reaching the standard of reasonable competence. Similarly, it is no defence for me, as an employer faced with a racial or gender discrimination action under the

${ }^{1}$ For the first, see J. Rentoul, "The Top Ten: Terrible Technology Predictions", The Independent, available at https://www.independent.co.uk/life-style/gadgets-and-tech/features/the-top-ten-terrible-technology-predictions-10281419.html (last accessed 7 September 2021); see "Worst Tech Predictions of All Time", The Telegraph, available at https://www.telegraph.co.uk/technology/0/worst-techpredictions-of-all-time/henry-ford-with-his-model-t/ (last accessed 7 September 2021) for the second.

2 A famous but tentative obituary (O. Fiss, "The Death of the Law?" (1986) 72 Cornell L. Rev. 1) was subsequently retracted: "The Law Regained" (1989) 74 Cornell L. Rev. 245.

3 I take the terms "capitalist" or "liberal" or "bourgeois" to be synonyms for "modern" here: for elucidation, see W. Lucy, Law's Judgement (Oxford 2017), 19-21. 
Equality Act 2010, to say that I'm a racist or a misogynist: those features of my character are ignored for the purposes of exculpation, although the law does register them as bases for initiating legal action. And, although there is a partial defence of loss of control (provocation) in English criminal law, the law ignores the fact that some of those accused of murder kill other people because they (the assailants) are very touchy, aggressive or bad tempered. Finally, note that the default standard of performance in English contract law is strict compliance: generally speaking, I simply must perform my contractual obligations and it is not good enough to try my best or make reasonable efforts.

These features of English law are not unique. They are commonplace within the common law world and also feature in civil law legal systems. Nor are they the only features of the substantive law of these legal systems that have the effect of ignoring much, but not absolutely everything, about the character, conduct and context of the law's addressees. ${ }^{4}$ Justice is not therefore blind, but it does take a very limited view of its addressees: the law sees us, but not in all our particularity and detail. In the law's gaze, we look like the people animating Nicola L.'s performance art piece, Red Coat (Same Skin for Everybody). ${ }^{5}$ Most of the differences that mark the actual people (there are 11) who wear the coat are obliterated, but not all. We can see that there are different, real people in there, but in broad outline they are made to look more or less the same by the coat. It is a layer over them, subsuming them under the same guise: different but also strikingly alike.

Law's abstract judgment (LAJ) is the label I give to modern law's tendency to ignore much about its addressees while, simultaneously, treating them in the same way and as if they were identical. I argue that LAJ has at least three components and one presupposition. ${ }^{6}$ The first is the presumptive identity component, so named because modern law usually sees its addressees not in all their particularity, but as identical abstract beings. The law's addressees are identical in two respects according to this component: they are regarded as the same in terms of those capacities, cognitive and physical, which enable humans to comply with achievable and intelligible legal standards; and they are accorded exactly the same entitlement to the same bundle of "formal" rights. LAJ's second feature is the uniformity component, which entails that, generally speaking, the law judges its addressees by reference to general and objective standards equally applicable to all. The idea that the same laws should apply to all addressees of the law is so powerful that it problematises laws which apply to particular

\footnotetext{
${ }^{4}$ Ibid., at 4-19 for fuller discussion.

5 Nicola L., "Performances", available at https://www.nicolal.com/performances.html (last accessed 26 September 2021).

${ }^{6}$ Lucy, Law's Judgement, chs. 1, 2.
} 
named persons or groups. This requirement, once apparently called "isonomy", is identical to some versions of the generality requirement of the rule of law ideal.

The limited avoidability component is the third feature of LAJ. It highlights the fact that in modern legal systems the application of the standards in play in the uniformity component is generally mitigated only by a limited number and range of exculpatory claims. The presupposition that informs LAJ is a conception of the legal person. It is assumed by each of the three components, since they take for granted the existence of beings and groups with two features. Those features are, first, the ability to understand the general and objective standards by which the law seeks to govern them and, second, the capacity to change behaviour in light of those standards. If the law's addressees lacked these features, then regulation by law would be pointless.

LAJ is an historically significant mode of legal judgment, its emphasis on generality and abstraction distinguishing it from feudal law. The latter consisted of different incidences tied to a variety of rigid roles to which a feudal Justitia could not be blind, since one's legal rights and obligations were determined by those roles. Two principal features of English feudalism ensured this. ${ }^{7}$ It was, first, a system of order in which economic production and the status, opportunities and life chances, along with the legal rights, duties and other incidents, of most members of the community depended upon holding and granting interests in land. And it was also, second, an order marked by the fact that some holders of interests in land exercised considerable private jurisdiction over others.

A consequence of these two features was that the legal system of feudal England explicitly and systematically distinguished between categories of addressee and, as a result, upheld a rigid system of social stratification and entrenched social immobility. There was no genuine sense in which all addressees of the law were regarded as the same before it; nor were the law's addressees always bound by the same laws. The law recognised a number of different legal statuses and these strictly determined one's legal rights and duties, liabilities and immunities. The legal "sorts and conditions of men" included, inter alia, that of Earl and Baron, Knight, serf, member of religious order, Clergy, Alien and Jew. ${ }^{8}$ These legal sorts and

\footnotetext{
7 The utility of the term "feudalism" and cognates is contested by some historians (the locus classicus is E. Brown, "The Tyranny of a Concept: Feudalism and Historians of Medieval Europe" (1974) 79 American Historical Review 1063-88). The simplistic characterisations of feudalism and feudal legality adopted here will not be of use to historians, but accord with what some historians and historically informed thinkers say: K. Marx, "Capital" I, vol. 35, in Marx-Engels Collected Works (London 1996), 706-51 and "Capital", III, Vol. 37 in Marx-Engels Collected Works (London 1998), ch. XLVII; P. Anderson, Passages from Antiquity to Feudalism (London 1974), part 2, I; C. Hill, The English Revolution 1640 (London 1955), Preface; J.G.A. Pocock, The Ancient Constitution and the Feudal Law (Cambridge 1987 (reissue)), 68-69 and chs. IV, V. A clear account of tenure and related matters in the early to late middle ages is C. Brooks, Law, Politics and Society in Early Modern England (Cambridge 2008), 322-41.

${ }^{8}$ F. Pollock and F. Maitland, History of English Law, vol. 1 (Cambridge 1968), 407.
} 
conditions were not open to one as different choices one might make. Rather, one's legal status was usually set for life and almost entirely a consequence of one's social rank when born. The qualifications "usually" and "almost entirely" are necessary because some degree of mobility existed between some sorts and conditions. This fact does nothing to undermine the judgment that feudal society was hierarchical and rigidly stratified; nor does it make implausible the claim that such "social immobility and hierarchy... suggest[ed] a view of rights as inherently unequal privileges enjoyed by the established estates". ${ }^{9}$

Modern legal systems lack the range of entrenched, explicit statuses and ranks, and thus the differentiated bundles of legal rights, duties and other incidences attached to them, characteristic of feudal legal systems. While truncated echoes of the notions of due process of law, of equal standing before and under the law, and of impartial application of the law were not unknown to feudal legal systems, thanks to the influence of Roman law, they are to the forefront of modern law's self-understanding. There is no single point at which this transition in the nature of law and its self-understanding occurred; it was a gradual process that went alongside the development of mercantile, capitalist economies. Indeed, the practical, emancipatory power of ideas about due process of law, equal standing, impartiality and equality of legal rights has been regarded as one of the principal drivers of the capitalist revolution. ${ }^{10}$ However, I argue here that one of the most significant results of this revolution and a defining characteristic of our recent legal past and present - LAJ - is destined for "the dustbin of history". ${ }^{11}$ The regulatory paradigm of which it is part is being superseded.

\section{Regulatory PARAdigms}

In a series of path-breaking essays, Roger Brownsword refined a distinction prefigured by Lawrence Lessig. ${ }^{12}$ If we take regulation to "encompass any instrument (legal or non-legal in its character, governmental or non-

9 N.E. Simmonds, The Decline of Juridical Reason (Manchester 1984), 42.

10 See M. Tigar and M. Levy, Law and the Rise of Capitalism, 2nd ed. (New York 2000), parts IV, V.

11 Trotsky's bon mot: B. Patenaude, Stalin's Nemesis (London 2009), 284.

12 L. Lessig, Code Version 2.0 (New York 2006), 72-74, 323-24, Appendix; see also his "Law of the Horse" (1999) 133 Harvard L. Rev. 501. Some of the Brownsword essays are: R. Brownsword, "What the World Needs Now: Techno-regulation, Human Rights and Human Dignity" in R. Brownsword (ed.), Human Rights (Oxford 2004); R. Brownsword, "Code, Control and Choice: Why East is East and West is West" (2005) 25 Legal Studies 1 (hereinafter "Code"); R. Brownsword, "In the Year 2061: From Law to Technological Management" (2015) 7 Law, Innovation and Technology 1 (hereinafter "2061"); R. Brownsword, "Law as a Moral Judgement, the Domain of Jurisprudence, and Technological Regulation" in P. Capps and S.D. Pattinson (eds.), Ethical Rationalism and the Law (Oxford 2017), ch. 7; and R. Brownsword, "From Erewhon to Alpha Go: For the Sake of Human Dignity Should We Destroy the Machines?" (2017) 9 Law, Innovation and Technology 117. The themes of these essays are expanded in his Law, Technology and Society (London 2019) and contained in capsule form in his Law 3.0 (London 2021). Both are discussed in W. Lucy, "Law School 2061" (2021) 84 M.L.R. 
governmental in its source, direct or indirect in its operation...) that is designed to channel group behaviour", ${ }^{13}$ then the distinction is between two broadly different approaches to that task and their correspondingly different forms and animating assumptions. These are different points on a spectrum, having been variously labelled as an East Coast regulatory approach versus a West Coast approach, as rules versus code and as law versus technological management. The latter term is Brownsword's and he elucidates it thus, as "typically involving the design of products or places, or the automation of processes ... [which] seeks to exclude (i) the possibility of certain actions which, in the absence of this strategy, might be subject only to rule regulation [and/] or (ii) human agents who otherwise would be implicated in the regulated activities". ${ }^{14}$

As an ideal-type regulatory form, technological management is principally a matter of prohibition and elimination, seeking to prevent certain forms of conduct or action ever arising by making them impossible. The best form of regulatory response to any particular social problem, on this view, is to ensure that the problem does not or cannot arise. Since success is not guaranteed, technological management entails more than simply creating "a designed environment (and/or controlled regulatees) with a required pattern of behaviour". ${ }^{15}$ For, having identified the required pattern, regulators must then "monitor whether the control system is producing the required pattern; and... respond (by fixing the problem) where the system needs to be adjusted". ${ }^{16}$ A particularly promising way of achieving a specific pattern of behaviour, for technological managers, is to foreclose alternatives by architecture and design. Barriers that one can pass through in only one direction and PCs that will not work unless one accepts the terms of use are quotidian instances of technological management.

By contrast, the ideal-type of law- or rule-based regulation requires regulators, first, "to adopt and declare a regulatory position ....[;] second ... to monitor responses to that position and to exert pressure for compliance; and...third... to take enforcement steps against regulatees who do not comply". ${ }^{17}$ Rule regulation operates through practical reason, since "on the East Coast, regulators speak to their regulatees, reasoning with them more or less successfully, [whereas] on the West Coast, regulators by-pass practical reason to design-in a solution of which regulatees might not even be aware". ${ }^{18}$ Rule regulators therefore not only assume that regulatees can understand what is required of them and act accordingly, but also allow them to decide whether or not to comply. West Coast regulators make no

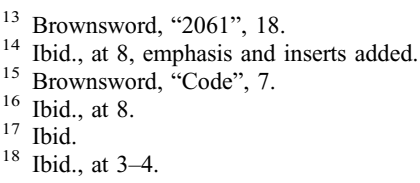


such assumption and, if it proves to be a more effective means of achieving their regulatory goal, will foreclose the possibility of non-compliance. None of the three principal components of the East Coast regulatory paradigm - promulgation, practical reason and enforcement - are vital to the West Coast paradigm; they are, at most, just some options among others for achieving regulatory ends.

A standard hypothetical by which to illustrate the contrast between rule regulation and technological management relates to road traffic regulation. The way rule regulators attempt to achieve the goal of having a maximum speed for traffic would be: (1) to set a maximum speed limit and publicise that; (2) to set penalties for exceeding the maximum and publicise them; and (3) ensure some means of enforcing those penalties against those who exceed the limit. A technological management approach to this goal would have no pre-commitments as to how to achieve it, except for displaying a preference for the most efficient method. And that method could well ignore each of the three steps that rule regulators regard as indispensable. But if, as now seems to be the case, cars can be designed so as not to exceed the speed limit in any particular area, technological managers are most likely to adopt that means to achieve their goal: the goal is designed-in to the means - the vehicle - by which breach of the goal used to be possible, albeit via human agency. ${ }^{19}$ The technological management approach here circumvents human agency as a means of breach, allowing it a role only in the construction of the solution (insofar as human agents are involved in process of designing and building the vehicles and the necessary traffic infrastructure). The agency of drivers with regard to both knowledge of the regulatory goal and the choice to comply is rendered redundant. If we can ensure that it is impossible for cars to exceed the speed limit in this way, then that is a more direct and parsimonious way of achieving our regulatory goal than telling regulatees what is required of them, telling them what will follow if they behave contrary to the requirement and leaving them to decide whether or not to comply. Smart regulators - those looking for the cheapest and most effective means of achieving regulatory goals must surely be technological managers.

Two general points are worth noting about this technological management response to traffic regulation. First, it could be achieved without any recourse to public law-making forums, like national legislatures, local government councils, law reform and policy-making bodies. Vehicle manufacturers could ensure adherence to the speed limit solely as a result of their own efforts. This might be thought problematic, since standard setting and enforcement of this kind is assumed to be a public, political-cum-state function, subject to discussion, scrutiny and oversight.

19 This possibility is almost in reach: see Tesla, "Autopilot and Full Self-driving Capability", available at https://www.tesla.com/support/autopilot (last accessed 7 September 2021). 
But this complaint about technological management - that it arrogates an important public function and its cognate processes to the private domain - is to some degree misplaced. One reason for this is that it constitutes a retrospective challenge to the way in which regulation was conceived at the outset of our discussion in this section; another is that there is no guarantee that rule regulation is always and ever "public" in the sense that involves the state.

As to the first reason, I do not deny that regulation could be conceived in a narrower or more discriminating way so as to embed something like a public/private distinction. But there are many such distinctions, not one, and the regulatory problem of trying to conduct human conduct does not appear qualitatively different on one side of the divide as compared to the other. ${ }^{20}$ Technological management is a regulatory strategy available equally to both (non-individual) "private" and "public" (state) actors. Each player can attempt to impose their regulatory solutions to particular problems and neither - be it a nation state, on the one hand, or a multinational corporation, on the other - has obviously greater salience or power than the other. ${ }^{21}$ The second reason reminds us, as Lon Fuller, the unacknowledged sage of rule regulation often did, that that form of regulation is just as useful and appropriate in "private" as in "public" (or state) domains. ${ }^{22}$ The moral is that it is not the regulatory form one adopts rule regulation or technological management - which determines the nature and significance of any particular public/private distinction.

The second point about this technological management response to traffic regulation is this: notice how easy and appealing it is! Assuming the technology is available at reasonable cost, how could we object to this way of ensuring compliance with the law? Making non-compliance impossible is obviously more than a matter of just ensuring that the law is not breached: it will surely also bring about a decline - perhaps at some point the complete eradication - of road traffic injuries and deaths. The benefits are so obvious and the costs so low that this technological management solution, like most such solutions, seems irresistible. This is not only so with regard to upholding and enforcing the criminal law, but also in relation to other matters of concern: if we can put robots in harm's way rather than humans, and use technology to prevent or reduce environmental degradation, it

${ }^{20}$ See W. Lucy and A. Williams, "Public and Private: Neither Deep Nor Meaningful?" in K. Barker and D. Jensen (eds.), Private Law: Key Encounters with Public Law (Cambridge 2013), ch. 2.

21 Do not assume, despite some contrary indications from Lessig (code can "perfect control" (Brownsword, "Code", 4) and "code is law" (ibid., at 5)), that control over technological management and code means that technological management solutions are either inescapable or impossible to subvert: see C. Reed and A. Murray, Rethinking the Jurisprudence of Cyberspace (Cheltenham 2018), at 86-101 for discussion.

${ }^{22}$ Numerous essays in K. Winston (ed.), The Principles of Social Order: Selected Essays of Lon L Fuller (Oxford 2002), part II, make the point; see also L.L. Fuller, The Morality of Law, revised ed. (New Haven 1969), ch. II. 
would be foolish not to, wouldn't it? The appeal of technological management ensures that, in Brownsword's phrase, it is the obvious "direction of regulatory travel", the path we seem bound to pursue. ${ }^{23}$

A final point about regulatory paradigms: note their connections with LAJ. LAJ is so closely and clearly connected to the East Coast regulatory paradigm that, when I use the term "law" in its general sense in what follows, I refer to that combination. LAJ and the East Coast paradigm not only share an identical conception of the (legal) person - a being, inter alia, able to understand directives and capable of behaving in accordance with them they also manifest a preference that those directives be general, applying in principle to all. Of course, choosing rule regulation does not entail that the rules one formulates must always be general in this sense; nor does it require that one regard the law's addressees as identical. But it assuredly inclines one in both directions. If rules are to count as rules, then they must have some degree of generality and this truth makes both the uniformity and presumptive identity components of LAJ salient. Whereas generality is the core of the former component, it is less directly related to the latter, but a connection nevertheless exists. That is because a preference for rule regulation via general (and thus genuinely) rule-like standards will quickly be challenged by the claim that this kind of equal treatment - the same rule is to apply to all - ignores differences between its addressees. The proponent of rule regulation must concede this point and either deny that those differences are significant or customise the rule so as to accommodate them. The former is the default position of LAJ and modern law.

That there is no such close connection between the West Coast regulatory paradigm and LAJ is obvious. LAJ's three components have no more significance within that paradigm than do the three constituents of rule regulation. Generality, identity and limited avoidability might be useful to a technological manager in some limited circumstances, but they constitute just as ponderous and blunt a response to particular regulatory problems as the East Coast edifice.

\section{Why DeATh Beckons}

There are two reasons why LAJ is doomed. Both are a matter of historical, political and intellectual context, one relating specifically to law, the other being more general. They are not, however, independent since, despite appearances, the first is a manifestation of the second. Furthermore, both illustrate the rise, and portend the ultimate triumph, of technological management and thus the death of law.

${ }^{23}$ Brownsword, "2061", 5 . 


\section{A. Pathologising Law}

For at least 50 years, some lawyers, insurers, policy-makers, politicians and others in the common law world have pathologised law. ${ }^{24}$ I do not mean that they regard the very idea of law as unhealthy or unwelcome. In fact, those who regard law as pathological would, simultaneously, extol the many virtues of their respective legal systems and the importance of the ideals, such as the rule of law, animating them. Living under the rule of law in accordance with a regime of fundamental rights is a minimum requirement of a good society for this group. They are not would-be tyrants, but they certainly have law-related doubts. They are troubled not by law's ideals but about their realisation, in this sense: actually existing legal systems appear to them to be deeply problematic means of ensuring societies live in accordance with the rule of law and human rights. The alleged problems are multiple, but many concern time and cost, while others highlight the supposedly baleful general consequences of increased levels of legal disputation, such as fraying ties of civility: "the litigation explosion" is a scourge upon us all. ${ }^{25}$ Law's pathology, on this view, is the conflict and expense generated by testing and resolving legal claims through litigation and these elements of the legal disease need management, perhaps even complete eradication. Law's ideals and values remain ostensibly untouched on this view, since it is law's realisation - through litigation, access to legal expertise and court systems - that is problematic. There is a sense among doubters in all the main common law legal systems that money spent on these matters is not well spent.

By labelling this group "doubters" and characterising their position as one that "pathologises" law, I imply neither that the group is conscious of itself nor that it explicitly espouses a shared pathologising agenda. Rather, the group consists of a diverse range of actors engaged in legal

24 Civil law is my focus here although the criminal law has also been affected. However, the process there has added complexities, one vivid difference being that major doctrinal categories and practices of criminal law and justice have been pathologised: see B. Wootton, Crime and the Criminal Law, 2nd ed. (London 1981) and F.A. Allen, The Decline of the Rehabilitative Ideal (New Haven 1981). Helpful discussions are B. Hudson, Justice in the Risk Society (London 2003); A. Ashworth and L. Zedner, Preventative Justice (Oxford 2014); M. Rich, "Should We Make Crime Impossible?" (2013) 36 Harvard Journal of Law and Public Policy 795.

25 Some relatively sustained articulations of this view are: F. Furedi, Courting Mistrust (London 1999); F. Furedi and J. Bristow, The Social Cost of Litigation (Chichester 2012); T. Brown, "The Social Costs of a Compensation Culture" in E. Lee (ed.), Compensation Crazy: Do We Blame and Claim Too Much? (London 2002). Many other statements of the view invoke anecdotal sources: see M. Galanter, "Real World Torts: An Antidote to Anecdote" (1996) 55 Md. L. Rev. 1093, 1094-98; R. Mullender, "Negligence Law and Blame Culture: A Critical Response to a Possible Problem" (2006) 22 Professional Negligence 2, 2-5; and A. Morris, "Spiralling or Stabilising? The Compensation Culture and Our Tendency to Claim Damages for Personal Injuries" (2007) 70 M.L. R. 349, 349-54. J. Hand, "The Compensation Culture: Cliche or Cause for Concern?" (2010) 37 J. L. \& Soc'y. 569 provides a fascinating comparison between media coverage of "compensation culture" and levels of legal claims. The work of political communitarians, like Amatai Etzioni, is often glibly associated with the critique of litigation, but see his Law and Society in a Populist Age (Bristol 2018), part two. 
practice, practical politics and policy-making, as well as lobbying and agenda-setting across a sizeable chunk of time. Furthermore, their lawyering, policy-making, lobbying and politics have usually been addressed to quite narrow subsegments of law's pathology, against, for example, the cost of legal advice and litigation in the criminal justice system or delays and complexity in the civil courts. But one undoubted consequence of the articulation and accumulation of many such particular critiques over a long period of time is the sense that law has become problematic, a cause of concern and in need of change or reform. That is the first step in the process of pathologising law.

The second, more dramatic step is changing the law or practices related to it. Setting aside change brought about by adjudication, the remaining sources of legal change are not exhausted by statutory intervention. Practice directions fall between these possibilities and can have significant effects. ${ }^{26}$ So, too, can changes in practices contiguous to the law: insurers refusing to offer cover for particular kinds of injury or loss can, for instance, serve to significantly reduce levels of litigation. And levels of litigation, judged by the number of civil law trials, have suffered a particularly striking decline in some of the principal common law jurisdictions at a time when they have never had more statute law, more lawyers and more expenditure on law-related activity. ${ }^{27}$

The decline in the US is numerically striking but looks fairly gradual. In 194015.2 per cent of civil cases filed in federal courts were resolved at trial, this number declining to 1.8 per cent (in trials of any sort) and 1.2 per cent (of jury trials) in 2002. ${ }^{28}$ One reason for the decline, according to John Langbein, was the adoption of the Federal Rules of Civil Procedure in 1938. Intended as a means of ensuring better pre-trial discovery, the rules, often amended and applicable in all US district courts, have in effect created a non-trial regime in both federal and state courts. ${ }^{29}$ Langbein's thesis is in many respects compelling but, of course, it has salience only within the US and it cannot explain the particularly marked decline of civil law trials in the US as between 1962 and 2002. ${ }^{30}$ Nor

${ }^{26}$ One example, from a long list: Ministry of Justice, "Practice Direction 3A: Family Mediation and Assessment Meetings", available at https://www.justice.gov.uk/courts/procedure-rules/family/practice_directions/pd_part_03a (last accessed 7 September 2021).

27 A point repeatedly made by M. Galanter in, e.g., "The Decline of Trials in a Legalizing Society" (2017) 51 Val. U.L. Rev. 559, 559-65; "The Vanishing Trial: An Examination of Trials and Related Matters in Federal and State Courts" (2004) 1 Journal of Empirical Legal Studies 459, 460; and "Law Abounding: Legalisation Around the North Atlantic" (1992) 55 MLR 1.

28 J.H. Langbein, "The Disappearance of the Civil Law Trial in the United States" (2012) 122 Yale L.J. $522,522-26$.

29 Ibid., at 569-71.

30 Documented in Galanter, "Vanishing", 461-74 and updated in M. Galanter and A. Frozena, "The Continuing Decline of Civil Trials in American Courts" (2011) Pound Civil Justice Institute, 1, available at https://www.poundinstitute.org/wp-content/uploads/2019/04/2011-Forum-Galanter-FrozenaPaper-1.pdf (last accessed 28 September 2021). For some complexities, see H. Kritzer, "The Trials and Tribulations of Counting Trials" (2013) 63 DePaul L. Rev. 415. 
can it explain the remarkable levels of decline in the number of civil trials in other common law jurisdictions.

In England and Wales there has been a relatively recent and precipitous decline in civil trial numbers in the Queen's Bench Division (excluding the Administrative Court), the figures having broadly increased year on year since 1938. Trial numbers began to decrease significantly in the 1990s and, more recently, Hazel Genn reports that "[t]he 2011 figures for the QBD show a continuing downward trend in proceedings being issued since 1998 and, although one can't see this clearly, there has been a $24 \%$ decline in numbers simply since 2006". 31 That is a decline of almost onequarter over a period of eight years, it being no surprise were that reduction echoed in actual trial numbers. The period 1955-2005 witnessed a significant fall in the number of county court trials, the downturn beginning in the mid-1970s. This decline has been accompanied, since 1980, by a huge increase in the number of small claims arbitrations, although this might actually be the result of simple re-description of trial events as arbitrations. $^{32}$

The decline in civil trial numbers in some Australian states is not quite as dramatic as in either the US or England and Wales, but it is seemingly inexorable (with the possible exception of Victoria). In New South Wales, for example, the number of civil filings in 1991 was just under 20,000; by 2009 it was less than half that number. ${ }^{33}$ The collection of data for civil trial numbers in Canada is, like Australia, conducted at Provincial rather than federal level and most of the studies that exist concern civil trial numbers in Ontario. These, too, reflect a notable fall, Herbert Kritzer reporting a reduction from roughly 5,000 trials per year in the mid-1970s to just over 1,000 in $2003 .{ }^{34}$

There are assuredly many different reasons for the striking reduction in civil law trials. In some common law jurisdictions, a pertinent cause of decline is statutory change, such as the introduction of the Federal Rules of Civil Procedure in the US, or fairly frequent changes in the organisation and structure of the court system, as in England and Wales. Other plausible reasons for the fall include changes in legal practice and the organisation of law firms as well as the adoption of "managerial judging", in which judges spend more time managing cases and ordering or suggesting settlement, as

${ }^{31}$ H. Genn, "Why Privatisation of Civil Justice is a Rule of Law Issue" (2012) F.A. Mann Lecture, 4-5, available at https://www.ucl.ac.uk/laws/sites/laws/files/36th-f-a-mann-lecture-19.11.12-professor-hazelgenn.pdf (last accessed 7 September 2021).

32 H. Genn, Judging Civil Justice (Cambridge 2010), 36 and Kritzer, "Trials and Tribulations", 418. For additional analysis of the civil trial figures for England and Wales, see H. Kritzer, "Disappearing Trials? A Comparative Perspective" (2004) 1 J.E.L.S. 735; and R. Dingwall and E. Cloatre, "Vanishing Trials? An English Perspective" (2006) 2006 Journal of Dispute Resolution 51.

33 D. Spencer, "The Decline of the Trial in Australia", available at https://pdfs.semanticscholar.org/1ed9/ 75a716a93c32e87de38fe7f2df017fa7908d.pdf (last accessed 7 September 2021), 3; also available in (2011) 30 The Arbitrator and Mediator 1 .

34 Kritzer, "Disappearing Trials?", 748-52. 
opposed to hearing and deciding trials. ${ }^{35}$ Yet it seems equally plain that this decline could not take place and go unremarked for long in an environment in which civil trials were regarded as an important and valuable part of legal and political culture. ${ }^{36}$ It would require a remarkable level of false consciousness to exult the institution of the trial as fundamental to the rule of law and citizenship while completely ignoring its state of health.

Judged by numbers, that state is poor. This is not particularly surprising once we recall that the civil justice systems of many common law jurisdictions have been regarded as being in a state of crisis for several decades. Crisis-talk is never good news: identity crises, emotional crises and funding crises are not signs that things are going well. And so it is with regard to civil justice. In England and Wales, one of the more recent crises began a few years before the publication of the Woolf Report in 1996. That

was only one of a number of similar reviews and reform programmes that started in California and Australia, were repeated in several Australian states and then seemed to spread around the world to New Zealand, several provinces in Canada, Hong Kong and Scotland. All were apparently undertaken in response to existing or impending crises in civil justice.... What was... [this] a crisis of and whose crisis was it? Why did civil justice systems around the world have to change at that particular moment?... What is intriguing is the crisis rhetoric and the sense of urgency about change. And even more curious is the fact that in many places the apparent crisis was occurring at a time of declining pressure on the civil courts. ${ }^{37}$

It seems, then, that there was and perhaps still is a crisis of civil justice but that neither its causes nor its consequences, save for one, have been delineated. This is surely an instance of "groupthink" in which group members share a particular view - be it a policy, a proposed product or any of a vast range of other strategies - without it having any reliable foundation, the biases of the group preventing critical evaluation. ${ }^{38}$ Doubters are united in accepting the existence of a civil justice crisis and this view has had one undeniable consequence, which is in fact a conglomeration of particular micro-responses to an alleged macro-level problem, namely, law's pathology. A particularly striking micro-level response to the alleged crisis of civil justice in England and Wales came about in the early 2000s. It was the creation by the courts of a legal duty to mediate before litigating in court. By 2003 it seemed that this duty was an absolute one, so that the

35 The classic discussion is J. Resnik, "Managerial Judges" (1982) 96 Harvard L. Rev. 376.

36 A near perfect characterisation of the doubter's view: "Trial is a disease, not generally fatal, but serious enough to be avoided at any reasonable cost": S. Gross and K. Syverud, "Don't Try: Civil Jury Verdicts in a System Geared to Settlement" (1996) 44 U.C.L.A. L. Rev. 1, 3.

37 Genn, Judging Civil Justice, 28, emphases in original.

38 See C. Sunstein and R. Hastie, Wiser (Cambridge 2015), part I, especially chs. 2, 3. Sunstein and Hastie claim that components of the original conception of groupthink (see I. Janis, Groupthink, 2nd ed. (Boston 1982)) are not supported by evidence: ibid., at 6. Many of the debacles examined in A. King and I. Crewe, The Blunders of Our Governments (London 2013) are blamed on groupthink: see ch. 17 . 
disputants simply had to engage in a process of mediation or alternative dispute resolution (ADR) before trial. If the victorious party declined to do so, the court was entitled to refuse them an award of costs under what is now CPR Part 36. ${ }^{39}$ The courts currently recognise that there are reasonable grounds for refusing mediation or ADR and that costs reductions or refusals under CPR are determined by the reasonableness or otherwise of the conduct of the litigating parties during and before the trial. Unwillingness to enter into mediation or ADR is now one factor among others which judges consider when making a costs order. ${ }^{40}$

If one pathologises law, in the sense of regarding trials as problematic, then it makes sense to reduce their incidence. Moves towards pre-trial mediation and settlement are therefore natural steps to take, particularly if "one of the greatest uses of judicial procedure is to bring the parties to a point where they will seriously discuss settlement". ${ }^{41}$ More radical steps are available and have been taken. If efforts towards pre-trial settlement and mediation do not discourage litigants, then ensuring that they bear all the costs of the trial process - what the UK Treasury and Ministry of Justice calls "full-cost recovery" 42 - in addition to the costs of legal advice and representation is a tempting move. Since trials are generally objectionable, those who insist on pursuing them should surely bear the cost: a public good is thereby converted into a private good payment for which must be made by those who benefit from it, that is, litigants. ${ }^{43} \mathrm{~A}$ step in the same direction is to withdraw or deny public funds, via legal aid and related means of financing legal advice and representation, for litigation and cognate costs. ${ }^{44}$

39 The high (or low) point being Royal Bank of Canada Trust Corporation Ltd $v$ Secretary of State for Defence [2003] EWHC 1479 (Ch), [2004] 1 P. \& C.R. 28, in which the MoD were refused costs for declining the offer of mediation. They did so because they sought a clear answer to what the trial judge accepted was an important legal question: see Genn, Judging Civil Justice, 92-103, for discussion.

40 See Halsey v Milton Keynes General NHS Trust [2004] EWCA Civ 576, [2004] 1 W.L.R. 3002; PGF II SA v OMFS Company 1 Ltd [2013] EWCA Civ 1288, [2014] 1 W.L.R. 1386; Gore v Naheed [2017] EWCA Civ 369, [2004] 1 W.L.R. 3002.

41 E.R. Sunderland, quoted in Langbein, "Disappearance", 548.

42 "The MoJ's policy is that fees in HM Courts \& Tribunal Service reflect the full cost of the services provided": Regulatory Policy Committee, "Impact Assessment: Court Fees, Cost Recovery", available at https:/www.gov.uk/government/uploads/system/uploads/attachment_data/file/336513/2014-03-27__RPC13-MOJ-1959_2__-_Court_Fees_-_Cost_Recovery.pdf (last accessed 7 September 2021). This policy seems designed to address the misplaced complaint in Furedi, Courting Mistrust, at ii and 41, that litigation is a "tax" on the public. The way in which the provision of a "public" service, available to the "public", is a tax on the "public" is not spelled out, unless what is meant is that it is paid for from general taxation.

43 Many have shown that stable legal systems with reliable means of dispute resolution are impure public goods. Two examples are J. Buchanan, The Limits of Liberty (Chicago 1975), ch. 7; and T. Cowen, "Law as a Public Good" (1992) 8 Economics and Philosophy 249. For a reminder of the general benefits of litigation, see Genn, "Privatisation", 15-17.

44 The Legal Aid, Sentencing and Punishment of Offenders Act 2012 initiated the most recent round of reductions to funding for access to legal advice and representation, some effects of which are catalogued in the Equality and Human Rights Commission, "The Impact of LASPO on Routes to Justice" (2018) Research Report 118, available at https://www.equalityhumanrights.com/sites/default/files/the-impact- 
Is there a general cure for law's pathology? The particular responses to it we have noted share a commonality which suggests that there is: law without litigation. But how could we have law without that form of contestation and dispute? It is a mistake to assume a necessary connection between law and adjudication, since one is conceivable without the other. It is perfectly possible to imagine law, understood as a system of subjecting human conduct to the governance of rules, without that specific means of resolving disputes about those rules. Disputes could be resolved by many alternative means: voting, lotteries, singing contests and reference to the elders, to name a few. ${ }^{45}$ So, if law is separable from adjudication, that opens up a range of options that could be used to resolve legal disputes. And the boldest option available is to make such disputes impossible, to engineer them out of existence. If we could make non-compliance with law impossible, ensure that contracts could never be breached, vehicles never driven negligently, then the space for dispute about the interpretation and application of legal rules would contract, possibly even disappear (since there is no obvious space for interpretation or application to take place). ${ }^{46}$ Technological management is, then, a means of eradicating law's pathology.

How might we explain the process of pathologising law? The wisdom of posing this question could be doubted, since that process is surely fully explained by the reasons the actors themselves - doubters - have for their positions on particular issues. Stating those reasons, as the actors articulate them, is in itself a sufficient explanation. I accept that articulating agents' reasons must be part of any plausible explanation of their conduct and beliefs, but insist that there is an additional and broader historical, economic and cultural context to agents' conduct and beliefs which adds salience to some repertoires of deeds over others and to some ideas and systems of belief over others. There is, I suggest, a broader explanatory context within which both pathologising law and technological management become particularly salient, appearing to be the most obvious and preferable responses to perceived problems. I now turn to that broader context.

\section{B. Sovereignty, Biopower, Governmentality}

[A] power whose task is to take charge of life needs continuous regulatory and corrective mechanisms. (M. Foucault, The History of Sexuality I, 144)

The way in which one conducts the conduct of men. (M. Foucault, The Birth of Biopolitics (Lecture 7 March 1979), 186)

of-laspo-on-routes-to-justice-september-2018.pdf (last accessed 28 September 2021); and in S. Moore and A. Newbury, Legal Aid in Crisis (Bristol 2017).

45 I follow Fuller's statement of law's guidance function while repeating his caution about assuming a strong connection between law and adjudication: Morality of Law, 46, 55; for some alternative means of resolving disputes, see S. Roberts, Order and Dispute, 2nd ed. (New Orleans 2013), ch. 7.

46 On self-executing "smart contracts" see P. de Filipi and A. Wright, Blockchain and the Law (Cambridge, MA 2018), part 2. 
Michel Foucault's later studies culminated in the discovery of three forms of power, each constituted by different mentalities, practices and institutional arrangements. ${ }^{47}$ While careful not to suggest that the three forms are luminously distinct, arising within precisely delineated periods such that the move from one to another represents an abrupt change in thought, practice and institutions, ${ }^{48}$ Foucault nevertheless allows us to sketch the broad differences between them with some confidence. Sovereign power, which consists of "the right to decide life and death", 49 derives from the power of the Roman patria potestas and characterises early modern government: ${ }^{50}$

[I]n its modern form - relative and limited - as in its ancient and absolute form, the right of life and death is a dissymmetrical one. The sovereign exercised his right of life only by exercising his right to kill, or by refraining from killing; he evidenced his power over life only through the death he was capable of requiring. The right which was formulated as the "power of life and death" was in reality the right to take life and let live. Its symbol, after all, was the sword..$^{51}$

Sovereign power was supplemented by biopower, exercised upon and within bodies and minds. The sovereign's ability to take away life, land, money and all other holdings became just one instance of power among many others, all "working to incite, reinforce, control, monitor, optimize, and organize the forces under it; a power bent on generating forces, making them grow, and ordering them, rather than one dedicated to impeding them, making them submit, or destroying them". 52 The sovereign's right of death is now "align[ed] ... with the exigencies of a life-administering power", the negative "counterpart of a power that exerts a positive influence on life, that endeavors to administer, optimize, and multiply it, subjecting it to precise controls and comprehensive regulations". ${ }^{53}$

This form of power operates at two levels. First, at the level of the individual body, conceived as something in need of discipline in order to optimise its capabilities and forces, accompanied by "the parallel increase of its

47 For an arch disavowal of an interest in power, accompanied by the admission that his work was nevertheless "quite involved with the question of power", see M. Foucault, Power: Essential Works 19541984, vol. 3 (London 2001), 326-27. My use of the terms "mentalities, practices and institutional arrangements" here and elsewhere is an effort to capture Foucault's thought that power exists both discursively and non-discursively, a matter of thought and word as well as conduct. He often used the term dispositif to express this: M. Foucault, Power/Knowledge: Selected Interviews and Other Writings, edited by C. Gordon and translated by C. Gordon and others (New York 1980).

48 M. Foucault, Security, Territory, Population: Lectures at the College de France 1977-1978, edited by M. Senellart and translated by G. Burchell (London 2007), 106-08 (hereinafter "STP").

49 M. Foucault, The History of Sexuality: 1 The Will to Knowledge, translated by R. Hurley (London 1979), 135 (hereinafter "HoS l").

50 "Government" is not a synonym for the state, the origins of which are later than that of sovereign power, but a synonym for Foucault's notion of governmentality. As to the relationship between them, "the state is an episode in governmentality": STP, 248.

51 Foucault, $\operatorname{HoS} 1,136$, emphases in original.

52 Ibid.

53 Ibid., at 136-37. 
usefulness and its docility, its integration into systems of efficient and economic controls". ${ }^{54}$ And, second, at the level of populations, "focused on the species body, the body imbued with the mechanisms of life and serving as the basis for biological processes: propagation, births and mortality, the level of health, life expectancy and longevity" ${ }^{55}$ Biopower "flourished in the seventeenth and the beginning of the eighteenth century... [and was] part and parcel of, and can only be understood on the basis of, the development of the great administrative monarchies". ${ }^{56}$

Governmentality, for Foucault, is a web of relations of power including but extending beyond both the power of life and death and the regulation of bodies and populations. It is also an analytical grid by which that web is conceived, allowing Foucault to illuminate the "ways of conducting the conduct of mad people, patients, delinquents, and children" which might also elucidate power in "phenomena of a completely different scale, such as an economic policy, for example, or the management of a whole social body". ${ }^{57}$ The substance of the idea is the "art of government", 58 the latter term far exceeding the work of the state to include "government" of one's self, the family, the flock, the congregation and the economy, while the former entails the various means, rationalities and mentalities through which government operates: "[t]here is then both a plurality of forms of government and the immanence of practices of government to the state."59 Foucault repeats Francoise de La Mothe Le Veyer's broad characterisations of the different forms of government in play in these various domains governance of oneself is a matter of morality, governing a family "part of economy", 60 while the "the 'science of governing well' [concerns] the state, which belongs to politics" 61 - but insists that ideas and procedures from one can be adopted and amended in another. Hence, "notwithstanding this typology, these arts of government refer to and postulate an essential continuity from one to the other". 62

According to Foucault, although "we live in the era of a governmentality discovered in the eighteenth century",63 the notion predates that. De La Mothe Le Veyer's characterisation dates from 1651, but Foucault claims that the realisation of an art of government for the state was at that point

\footnotetext{
54 Ibid., at 139.

55 Ibid. An earlier statement of the hallmarks of biopower and biopolitics is M. Foucault, Society Must be Defended: Lectures at the College de France 1975-1976, edited by M. Bertani and A. Fontana, translated by D. Macey (London 2003), Lecture of 17 March 1976 (hereinafter "SMBD").

56 Foucault, STP, 107

57 M. Foucault, The Birth of Biopolitics: Lectures at the College de France 1978-1979, edited by M. Senellart and translated by G. Burchell (London 2008) 186 (hereinafter "BoB").

58 Foucault, STP, 92.

59 Ibid., at 93.

60 Ibid.

61 Ibid., at 93-94.

62 Ibid., at 94, emphasis added.

63 Ibid., at 109 .
} 
blocked by, on the one hand, thinking of the state by reference to the model of sovereign power and, on the other, by regarding the family as the alternative model for state government. The "unblocking of the art of government was linked to the emergence of the problem of population", ${ }^{64}$ the realisation that population gives rise to specific phenomena, that it has "its own regularities: its death rate, its incidence of disease, its regularities of accidents. Statistics also shows that the population also involves specific aggregative effects ...: major epidemics, endemic expansions, the spiral of labour and wealth... [as well as], through its movements, its customs, and its activity, ... specific economic effects". ${ }^{65}$

This realisation meant both that the model of family provided no guidance as to the nature of state government and that the force characteristic of sovereign power was redundant. Once the unique effects of population are noted, population becomes the final end of state government and that is a matter of improving "the condition of the population, ... increas[ing] its wealth, its longevity and its health". ${ }^{66}$ This generates a governmental regime Foucault calls "“biopolitics'... [,] the attempt, starting from the eighteenth century, to rationalize the problems posed to governmental practice by phenomena characteristic of...human beings forming a population: health, hygiene, birthrate, life expectancy, race". ${ }^{67}$ These problems are too vast to be comparable to the common burdens which face family units and, of course, the sword is an inappropriate means to solve them. The instruments that governments converge upon instead are ones "immanent to the field of population ... acting directly on the population itself through campaigns, or, indirectly, by, for example, techniques that, without people being aware of it, stimulate the birth rate, or direct flows of population to this or that region or activity". ${ }^{6}$

With regard to state government, Foucault noted two broad types, two different arts of government, with general differences in the mentalities, practices and institutions characteristic of each. The first arises from a prestate art of government which was the model of the pastorate, being a continuation of the pastoral idea of the Government or economy of souls into the kingly realm of sovereign power: the sword as an instrument of government is conjoined with something close to a minister's concern with the well-being of his congregation. From the late sixteenth century, that model was in part co-opted into an authoritarian art of government, in which the state is central. Authoritarian governmentality's intellectual rationale is the complex idea of reason of state and its principal instrument is "police", broadly conceived. ${ }^{69}$ The eighteenth century witnessed the birth

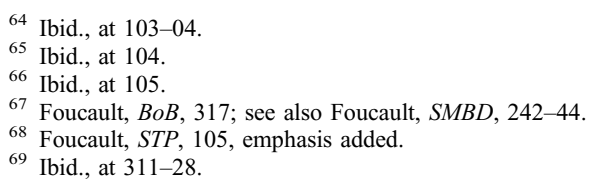


of a new "liberal" art of government, in which state, economy and multiple other agents and actors came to be both instruments and products of power, constituting webs of conduct by means of prohibitions, permissions, alliances and choices, all aided by a rich body of economic and social scholarship and policy guidance. ${ }^{70}$

It is plain that Foucault regards the three forms (sovereign power, biopower and governmentality) as an overlapping accumulation rather than a sequence. It is equally clear that governmentality, the last and pre-eminent instalment in the accumulation, must itself now be tweaked. ${ }^{71}$ But the sheer pervasiveness of power as disclosed by the notion of governmentality means that it provides a fruitful explanatory context within which to understand both technological management and the process of pathologising law. While Foucault died before the possibilities opened up by the former materialised, and even though he said nothing explicit about the latter, his views about governmentality illuminate both. ${ }^{72}$

As to pathologising law, it is plausible to regard litigation as an effect of population in this sense: as the populations and economies of Western industrial nation-states have grown so, too, have levels of litigation. If we set aside the question as to whether or not litigation levels in these states have genuinely increased, it is plain that some think that they have and that that is a good thing. ${ }^{73}$ Doubters do not take that view. Such an increase is a regrettable state of affairs for them, since it bespeaks the erosion of tight and meaningful social bonds, constrains service providers such as health care professionals and public bodies in the performance of their duties, hampers private enterprise, and replaces an ethic of care and responsibility with one of profit (and compensation) seeking. ${ }^{74}$ Doubters rarely spell out exactly how litigation brings about these effects, but it can presumably do so both as a threat, hanging over individuals, public bodies and private enterprises like a sword of Damocles, and as an already existing constraint in the form of legal precedents embodied in every day practice (like the warning label on one's take away coffee cup in some jurisdictions). When the supposedly baleful consequences of allegedly large increases in levels of litigation are combined with the claim that litigation is, in

70 This blunt characterisation of the arts of state government is unpacked in ibid., at 191-361 and throughout Foucault, $B o B$.

71 On the pre-eminence of governmentality, see Foucault, STP, 108.

72 He died on 25 June 1984; many date the birth of the internet to 1 January 1983. Hence, "Foucault was not writing about the Internet. He was not even writing about the twentieth century" (J. Boyle, "Foucault in Cyberspace: Surveillance, Sovereignty, and Hardwired Censors" (1997) 66 U. Cin. L. Rev 177, 187), although he often claimed his historical works were histories of the present: see M. Foucault, Discipline and Punish (New York 1978), 31. Clearly, histories of Foucault's present need not be the same as histories of our present.

73 For an introduction, see T. Eisenberg, S. Kalantry and N. Robinson "Litigation as a Measure of Wellbeing" (2013) IEL Paper in Comparative Analysis of Institutions, Economics and Law No 15, available at http://polis.unipmn.it/pubbl/RePEc/uca/ucaiel/iel015.pdf (last accessed 7 September 2021).

${ }^{74}$ See note 25 above. 
multiple senses, expensive (lawyers' fees have seemingly spiralled out of control and the costs of running legal systems are ever increasing), then we can see why it is regarded as a terrible drain on the common weal.

Since litigation is not as serious an effect of population as some mentioned by Foucault, it might be thought a mistake to view it as one. Some effects of population are constant and serious (epidemics, for instance) while others may be more pressing at one time rather than another. Yet others might arise at only one particular historical juncture and could well be a product as much of perception as "brute fact". Of the contemporary effects of some current populations, such as infertility, longevity, levels of traffic accidents, none may be unique except perhaps in their scale and potential consequences. Increased levels of litigation are plainly not a constant effect of population, arising wherever populations exist. But, just as epidemics and birth rates can be charted and predicted our knowledge of them being reasonably robust - so, too, can levels of litigation. The lack of a standard against which to assess the propriety of any particular level of litigation means, however, that its "problematic" status should, in general, be an open question. Currently, an increase in the mortality rate in any Western state would be regarded as regrettable and something that must be arrested, the care and longevity of populations being fundamental in these states. ${ }^{75}$ An increase in the number of cases processed in the legal systems of such states, on the other hand, should be a matter for neither celebration nor concern, although it is surely worthy of investigation. For doubters, such an increase is deeply problematic, a social problem to be addressed alongside others, that perception being common in several different jurisdictions and having given rise to a legion of government reports, committees of inquiry and task forces. That such activity has gone hand in hand with a decrease in the number of civil law trials in many of those jurisdictions is truly remarkable.

Governmentality's biopolitics strand concerns "the social, cultural, environmental, economic and geographic conditions under which humans live, procreate, become ill, maintain health or become healthy, and die"; its objects thus include "the family,... housing, living and working conditions, ... 'lifestyle', ... public health issues, patterns of migration, levels of economic growth and... standards of living". ${ }^{76}$ And increased levels of litigation can plausibly be added to this list. Like governmentality's other objects, litigation levels can become both a problem of the bodypolitic, affecting the wealth and well-being of the population as a whole, and a problem for the individuals whose lives are marred, financially and psychologically, by involvement in litigation. In that respect they can be seen in the same light as the social ills, such as sickness, unemployment

\footnotetext{
75 As the current COVID-19 pandemic makes clear.

76 Both quotations are from M. Dean, Governmentality, 2nd ed. (London 2010), 119.
} 
and industrial accidents, against which states and individuals insure. Indeed, the invention and implementation of widespread social insurance, which many Foucauldian scholars think heralds the discovery of a new and problematic "social domain", represents a change in emphasis within biopolitics. ${ }^{77}$ It marks an appreciation that supposedly "natural" and aleatory effects of population, like disease, are just as much a consequence of "social" factors as are the rate of accidents at work or on the roads. Furthermore, whether and how an alleged problem like increased levels of litigation or accidents at work come to be regarded as a malign effect of population does not depend only upon it being a genuine "social problem" causing clear, quantifiable social harm; it is sometimes enough for it to be perceived as such. Foucault is clear that perception is every bit as effective in constructing a social problem or object of concern as are allegedly "objective" determinants such as mortality rates or levels of contagion. ${ }^{78}$

With regard to technological management, the accumulation of Foucauldian forms of power explains the salience of the current direction of regulatory travel. It also re-describes, in broader historical and theoretical terms, that process, since technological management is an instance of contemporary governmentality. First, the direction of travel: regulation in Western liberal societies has become more pervasive and plural, being exercised in many different forums through a multitude of agencies, practices and mentalities, few of which register or represent a version of the public/private distinction: "modern forms of government... are the associations formed between entities constituted as 'political' and the projects, plans and practices of those authorities - economic, legal, spiritual, medical, technical - who endeavour to administer the lives of others in the light of conceptions of what is good, healthy, normal, virtuous, efficient or profitable."79

Technological management is a brilliantly effective means of administering the lives of others, a particularly salient governmental technology because increasingly easy to implement and effective across any domain dependent upon IT. It is first among equals including "the complex of mundane programmes, calculations, techniques, apparatuses, documents and procedures through which authorities seek to embody and give effect to governmental ambitions". ${ }^{80}$ Indeed, software and code are now the media

${ }^{77}$ See the essays by R. Castel (ch. 14), D. Defert (ch. 11), J. Donzelot (ch. 8) and F. Ewald (ch. 10) in G. Burchell, C. Gordon and P. Miller (eds.), The Foucault Effect (London 1991) and note the capsule statement in Dean, Governmentality, 152-53. One of Foucault's statements of the point is SMBD, 24344.

${ }_{78}^{78}$ See Foucault, $\operatorname{HoS} 1,118-19$ and Foucault, $S M B D, 252$ for a discussion of the problem of degeneracy.

79 P. Miller and N. Rose, Governing the Present (Cambridge 2008), 55.

80 Ibid. For discussion of instances of technological management actually and potentially supplementing and displacing law, see chs. 8-12 of Brownsword, Law, Technology and Society; J. Cohen, Between Truth and Power: The Legal Constructions of Informational Capitalism (New York 2019), part II; R. Susskind, Online Courts and the Future of Justice (Oxford 2019), part IV; Lord Sales, "Algorithms, Artificial Intelligence and the Law" (2020) 25 Judicial Review 46; and the sources in note 85 below. 
in which those programmes, calculations, techniques etc., exist, are monitored and delivered.

Is the claim that contemporary governmentality just is technological management too quick, an elision of two different notions rather than an explanation of the effect of one upon the other? No, for although there is a sense in which the two are blending into one another, there is a reason for that: governmentality makes technological management salient. How? Note again this section's epigraph about biopower: "a power whose task is to take charge of life needs continuous regulatory and corrective mechanisms." If that is right as a characterisation of biopower, itself a part of governmentality, then the appeal of technological management as a regulatory choice becomes obvious. First, because once the need for continuous regulatory and corrective mechanisms becomes apparent among all instruments of governmentality (public, private, group and individual), and once time and effort are devoted to answering that need, the knowledge and processes involved cannot and will not be unlearned or forgotten. And, second, because technological management simply is a sophisticated, continuous regulatory and corrective mechanism. Or, more accurately, it provides a vast range of continuous regulatory and corrective mechanisms designed into architecture, the environment and code which either completely obviates recourse to the agency of regulatees or radically reduces it.

The latter claim seems contrary to the view expressed by both Foucault and some leading Anglo-Foucauldians that governmentality, particularly liberal governmentality, operates through agency. So, for example, in reminding us both that "[p]ower is exercised only over free subjects, and only insofar as they are free" and that regulatees can always resist the effort to conduct their conduct by counter-conducts, Foucault is emphasising the importance of agency. ${ }^{81}$ This fits neatly with Nikolas Rose's view that, while

[g]overning is a genuinely heterogeneous dimension of thought and action something captured to some extent by the multitude of words available to describe and enact it... [it is] [n] evertheless ... possible to differentiate the exercise of power in the form of government from simple domination.["] To dominate is to ignore or to attempt to crush the capacity for action of the dominated. But to govern is to recognise that capacity for action and to adjust oneself to it. To govern is to act upon action. ${ }^{82}$

Mitchell Dean strikes a similar refrain, observing that government is not simply a

means to order people about or move things around. Rather, government... involves some sort of attempt to deliberate on and to direct human conduct.

\footnotetext{
${ }^{81}$ Foucault, Power, 336-40; Foucault, STP, 353 ("'a condition of governing well is that freedom, or certain forms of freedom, are really respected"). On counter-conducts see ibid., at 194-200 (in the pastorate) and 355-57 (in modern governmentality).

${ }^{82}$ N. Rose, Powers of Freedom (Cambridge 1999), 4, emphasis added.
} 
From the perspective of those who seek to govern, human conduct is conceived as something that can be regulated, controlled and shaped to specific ends.... [G]overnment... involves the attempt to shape rationally human conduct. ${ }^{83}$

But there is no conflict between these claims, holding that governmentality assumes (and perhaps even values) agency, and my claim that contemporary governmentality is technological management, the latter often being and increasingly likely to become a means of circumventing agency. For, although the claims of Foucault, Rose and Dean were assuredly once true, they will not long remain so. Prior to the advent of full-blown technological management, governmentality in general - and liberal governmentality in particular - did work through the agency of regulatees, that agency itself being a potential source of counter-conducts. There was no alternative to "the attempt to shape rationally human conduct". But full-blown technological management offers a code-based alternative while according no presumptive value to agency and, indeed, will surely ignore the latter when that is the most efficient regulatory response. ${ }^{84}$ That is so whether or not the regime of governmentality in question is liberal. ${ }^{85}$

Of course, one may still maintain that, although technological management routinely circumvents the agency of regulatees, it is nevertheless driven by the agency of those who design various instances of technological management. Thus designers of schemes of technological management might respect the agency of regulatees either as a default, flowing from their recognition of regulatees as fellow human beings, or as a result of deliberate exposure to respect for agency through legal and related training. This ameliorist response to technological management, which attempts to imbue respect for agency, rationality and the rule of law among technological managers, is undoubtedly easier to achieve when those managers are human beings. ${ }^{86}$ However, the existence of machine learning, in which computer programmes learn to improve their performance of tasks from experience, that learning being a result of the implementation of algorithms and levels of data mining beyond human capabilities, means that we

83 Dean, Governmentality, 18, first emphasis in the original, second emphasis added.

84 The regulatory wrangling manifest in decisions like Judgment of 13 May 2014, Google Spain v AEPD and Mario Costeja González, C-131/12, EU:C:2014:317, and case Judgment of 24 September 2019, Google v CNIL, C-507/17, EU:C:2019:772, in which state forms of governmentality come into conflict with resistant non-state forms, illustrates that the agency implicit in conducting conduct and resisting the conduct of conduct - via technological management - is still a live option for these actors. Both would surely love either to be able to engineer out non-compliance or make regulation impossible.

85 There seems to be no qualitative difference between technological management in liberal and non-liberal societies: see D. Mac Sithigh and M. Siems, "The Chinese Social Credit System: A Model for other Countries?" (2019) 82 MLR 1034; and M. Zalnieriute, L. Bennett Moses and G. Williams, "The Rule of Law and Automation of Government Decision-making" (2019) 82 MLR 425. Note that the vanguard for the development of "digital tracking" medication is the US: I. Goold, "Digital Tracking Medication: Big Promise or Big Brother?” (2019) 11 Law, Innovation and Technology 203.

86 As embodied in Brownsword, "2061" and M. Hildebrandt, "Law as Information in the Era of Data-driven Agency” (2016) 79 MLR 1. 
already live in an age of "data-driven agency". 87 The "surge of data-driven agency that is on the verge of saturating our environment" not only elides the distinction between online and offline worlds, "engineering the cyberphysical scaffolding that puts any thing online"; 88 it also puts us face-to-programme-cum-algorithm with non-human agents eminently capable of technological management. And since the exact way in which machine learning works is vastly complicated, depending upon "black box" algorithms and processes of data mining that appear inexplicable, building respect for agency and the rule of law into data-driven agents is a hugely difficult task. ${ }^{89}$

That contemporary governmentality no longer needs to operate through agency, since technological management can usually engineer regulatory solutions without it, suggests one way in which this eighteenth to twentieth century form of power must be tweaked for the twenty-first. Removing the agency of regulatees from the regulatory environment does not mean it disappears completely, only that it is impossible for regulatees to fail to comply with particular regulatory requirements. They might comply with a requirement that they cannot fail to comply with for what they regard as good reason, the deliberative process leading to that judgment undoubtedly being an instance of agency. Furthermore, there is room for Foucauldian counter-conducts, albeit not with regard to the requirement non-compliance with which is impossible. The hardware and software used in technological management is neither infallible nor immune to attack, various instances of it having already been hacked and either held hostage or debilitated..$^{90}$ But such counter-conducts, whatever the specific reasons behind them, are at best on behalf of rather than by regulatees: few of those using bitcoin or enmeshed in the Chinese social credit scheme have the means to assess their technological infrastructure, never mind undermine it.

The combination of machine learning and ubiquitous computing suggests another tweak. For, while Foucault was keen to emphasise the sheer pervasiveness of power, having coined the term governmentality in part to highlight its many different sites and instrumentalities, its sites and instrumentalities have been and are being massively expanded by the

${ }^{87}$ Hildebrandt, ibid., at 2; see also M. Hildebrandt and K. O'Hara (eds.), Life and Law in the Era of Datadriven Agency (Cheltenham 2020).

${ }^{88}$ Hildebrandt, "Law as Information", 7, 4. An early version of the "every thing in the world online" story is A. Greenfield, Everyware: The Dawning Age of Ubiquitous Computing (Berkeley 2006), updated in his Radical Technologies: The Design of Everyday Life (London 2017).

89 See L.H. Gilpin et al., "Explaining Explanations: An Overview of the Interpretability of Machine Learning" (2019), for discussion of "XAI", the attempt to make artificial intelligence explicable, available at https://arxiv.org/abs/1806.00069 (last accessed 2 September 2021). "Deep learning networks" or "deep neural networks" seem to be particularly opaque - a matter of "deep obscurity": Greenfield, Radical Technologies, 254.

90 A relatively recent instance (a Twitter hack that thwarted numerous bitcoin transactions): "Twitter Hack: Exchange 'Blocked 1,000 Bitcoin Transactions"”, $B B C$, available at https://www.bbc.co.uk/news/technology-53485170 (last accessed 2 September 2021). 
move to "online everything". In 2006 Adam Greenfield dubbed the end point of this process "everyware", where

the garment, the room and street become sites of processing and mediation. Household objects from shower stalls to coffee pots are reimagined as places where facts about the world can be gathered, and acted upon. And all the familiar rituals of daily life - things as fundamental as the way we wake up in the morning, get to work, or shop for our groceries - are remade as an intricate dance of information about ourselves, the state of the external world, and the options available to us at any given moment. ${ }^{91}$

The technological capacity to realise "everyware" exists now and the processes of behavioural monitoring and information gathering it portended are now utilised, and their outcomes monetised, by the giants of contemporary surveillance capitalism..$^{92}$ In the twenty first century, governmentality's scope is thus far greater, and its capacity to penetrate every aspect of life much deeper, than it was in the twentieth.

In some brief but remarkably prescient remarks 30 years ago, Gilles Deleuze, a former colleague of Foucault, attempted to characterise contemporary changes in Western societies which he thought required a slight shift in the latter's understanding of biopower and thus of governmentality. Deleuze claimed that the familiar institutions and structures of disciplinary biopolitics (prisons, hospitals, factories, schools, the family) were breaking down. These "sites of confinement" were being replaced by spaces that presented new freedoms, "the breakdown of the hospital" giving rise to "community psychiatry, day hospitals, and home care". ${ }^{93}$ But such spaces are also domains in which mechanisms of control operate that are "as rigorous as the harshest confinement". ${ }^{94}$ Deleuze suggested that Western societies were becoming "control societies [where]... the key thing is no longer the signature or number but a code: codes are passwords, whereas disciplinary societies are ruled... by precepts. The digital language of control is made up of codes indicating whether access to some information should be allowed or denied". ${ }^{95}$ While the details of Deleuze's point are not easily translatable into the argument offered here, his overarching thought - that social technological changes are afoot which are illuminated by but require amendments of Foucault's insight - certainly is. The notion of governmentality illuminates the present just as much as periods of the past. And it does so even though aspects of our present are far beyond Foucault's imagining.

\footnotetext{
91 Greenfield, Everyware, 1-2.

92 For the hallmarks of this new form of capitalism, see S. Zuboff, The Age of Surveillance Capitalism (London 2019), part I.

93 G. Deleuze, Negotiations, 1972-1990 (New York 1995), 178.

94 Ibid.

95 Ibid., at 180 .
} 


\section{CODA}

Is the story of the death foretold here plausible or informative? And would that death really be cause for regret? The best response to the first question is a brief recap of the argument. I argued that law, specifically that form of it dubbed LAJ and the East Coast regulatory framework of which it is part, is dying, its death being hastened by a combination of pathologising law and the rise of technological management. Further, I claimed that both have been made salient as mentalities, or ways of thinking, and as institutional responses to perceived regulatory and related problems, by the knowledge, procedures and modes of thought captured in Foucault's idea of governmentality. Taken as the conduct of conduct, the latter describes and illuminates the myriad ways in which we, individuals, groups, institutions and hybrid alliances of each, structure and constrain our thought, deeds and modes of existence. ${ }^{96}$ That structuring and constraining operates through and upon the individual self and body, and through and upon groups of such selves, as members of a species or population. This diverse form of power is information-driven, dependent upon knowledge of the individual (their conduct, capacities, inclinations and shortcomings) and of the population (the incidence of illness, disease, fertility and the number of accidents) and, in the early twenty-first century, is most obviously realised by technological management.

The plausibility or value of this Foucauldian story might be challenged both from within and without. The external challenge denies that the notion of governmentality has any explanatory capacity, it being marred by the insufficiencies that mark all of Foucault's thought about power. That thought has been subject to much discussion, ranging from matters of intellectual genesis (concerning, for example, the correct characterisation of the relation between biopower and governmentality) to the historical bases of his claims. But the objection just mooted is more serious than these incremental concerns, holding that Foucault's understanding of power is incoherent or "systematically ambiguous". 97 Part of the alleged ambiguity arises because Foucault's notion of power is supposedly both nonnormative, being "borrowed from the empiricist tradition", 98 and emancipatory, illuminating the constraints (intellectual and physical, individual and institutional) under which life in modernity is lived. Since emancipation, by definition, is a matter of liberation from a more to a less (or non-) baleful

\footnotetext{
96 Thus governmentality "concern[s] the relation between self and self, private interpersonal relations involving some form of control or guidance, relations within social institutions and communities and, finally, relations concerned with the exercise of political sovereignty": Burchell et al., The Foucault Effect, 2-3.

97 J. Habermas, "Some Questions Concerning the Theory of Power: Foucault Again" in M. Kelly (ed.), Critique and Power: Recasting the Foucault/Habermas Debate (London 1994), ch. 4, 83. A more limited "internal" critique of Foucault's thinking about power is found in C. Taylor, Philosophy and the Human Sciences: Philosophical Papers 2 (Cambridge 1985), ch. 6, 174-77.

98 Habermas, "Some Questions ", 96.
} 
situation, some criteria of improvement are necessary and they surely must, by definition, be normative. Furthermore, if this move can be made within Foucault's schema, then another problem allegedly arises, since emancipation of this kind is the result of knowledge about power. And that, it seems, is an instance of knowledge thwarting power rather than being power, as Foucault insists. ${ }^{99}$

I state this challenge and some of its component parts conditionally, because it is genuinely uncertain whether or not it or they hit home; there is, indeed, doubt as to whether there was any joinder of issue in the broader Foucault/Habermas debate of which they were part. ${ }^{100}$ It is nevertheless plain that Habermas's effort to corral Foucault's view of power into something like the normative-cum-communicative conception he espoused himself was wasted. For, although Foucault never had the opportunity to respond to it, the Habermassian conception and the vision of social theoretical inquiry of which it is part are very different to any understanding Foucault ever offered of his own work. ${ }^{101}$ The criticism that Foucault's conception of power is ambiguous because, although ostensibly non-normative it must of necessity be normative, therefore seems to substitute Foucault's concerns for those of others. If that is so, then the weight of this challenge is indeterminate and it cannot undermine the argument offered here.

The challenge from within comes principally from those Anglophone jurists most concerned with Foucault's account of law. Some of these scholars hold that Foucault's understanding of law is implausible because he equates it with sovereign power and, since sovereign power has been marginalised by the development of biopower and governmentality, he lacks an account of law as it exists in contemporary societies. ${ }^{102}$ On this view, the death foretold here is an old and utterly unsurprising story, that description being a flowery way of characterising the move from societies in the thrall of sovereign power (and law) to those in the grip of biopower and governmentality (and a supposed absence of law). This story might be plausible, but it is not informative, except as a reminder of the eccentricity of Foucault's thinking about law. For, with the exception of Foucault, we are all aware of law's importance in contemporary societies, there never having been more lawyers, more law and more spending on law-related activity. ${ }^{103}$

99 A more obviously Foucauldian account of such emancipation is that it is an instance of counter-conduct, being a product of knowledge/power. On the latter see Foucault's "Truth and Power" in P. Rabinow (ed.), The Foucault Reader (New York 1984), 51.

100 See the essays in part II of Kelly, Critique and Power, for an overview; Foucault died during the discussion about a formal debate with Habermas, the two having been unable to agree a topic (ibid., at 24).

101 The closest Foucault came to describing his work in terms almost congenial to Habermas is in "What Is Enlightenment?" in Rabinow, The Foucault Reader, 32-50. See ch. 7 of Kelly, Critique and Power, for Habermas's thoughts on this essay.

102 A classic statement of this view is A. Hunt and G. Wickham, Foucault and Law (London 1994), chs. 2, 3 .

103 See the essays by Galanter in note 27 above. 
This challenge rests entirely upon the exegetical claim that Foucault thinks law can only ever take the juridical form we find within regimes of sovereign power. And, while there is undoubtedly some support for that claim in Foucault's work, a broader view of his corpus shows that it is uncharitable. For, in addition to claims that equate law with sovereign power, there are also numerous instances in which Foucault notes that law's form has changed and expanded, that a new way of thinking about and deploying law has come to pass. That change comes with the rise of both the disciplinary aspect of biopower and biopower's concern with population and its effects. Law's form is no longer analogous to the sword but rather a form or a way of realising the norm and ensuring normalisation. ${ }^{104}$ In managing the body in prison, school, the hospital, factory and the like, standards are set for performance and used as a measure. They are targets and thus norms in the sense of goals to be achieved or aimed at, this process being labelled "normation" 105 by Foucault. Norms as goals or targets can, of course, also be deployed across populations, used as standards for things like levels of literacy and educational attainment; but norms, admittedly in the different sense of the normal or usual or average, can also be inferred from expected levels of things like disease, accidents, unemployment etc. Knowing the incidence of a particular disease in a population, its "normal" level, allows some degree of planning in response to it. On this view, the normal comes first and it is against that which the abnormal is measured: this near statistical process, a hallmark of modern governmentality, Foucault calls "normalisation". ${ }^{106}$

There is little doubt that Foucault thought contemporary law complicit in both processes, since it "can...function by formulating norms, thus becoming part of a different sort of power that 'has to qualify, measure, appraise, and hierarchize rather than display itself in murderous splendor"'. ${ }^{107}$ But he did not regard law as unique in performing this role, it being only one instrument of regulation or governmentality among many: "the judicial institution is increasingly incorporated into a series of apparatuses (medical, administrative, and so on) whose functions are for the most

104 Versions of this view are defended in V. Tadros, "Between Governance and Discipline: The Law and Michel Foucault" (1998) 18 O.J.L.S. 75, 92-101; F. Ewald, "Norms, Discipline, and the Law" (1990) 30 Representations 138; and in note 60; and, with a different emphasis, by J. Martire, A Foucauldian Interpretation of Modern Law (Edinburgh 2017), chs. 2, 4. This view is not far removed from the account of law offered in part III of Hunt and Wickham, Foucault and Law, although they regard that account as an alternative to Foucault's. Original versions of the view appear in more and less developed forms in M. Foucault, Abnormal: Lectures at the College de France 1974-1975, translated by G. Burchell (London 2003), Lecture of 12 February 1975; Foucault, Power, 56-87; SMBD, Lecture of 14 January 1976; $\operatorname{HoS~1,~part~five;~and~STP,~5-6;~and~in~the~Lectures~of~} 25$ January, 1 February and 8 February 1978. B. Golder and P. Fitzpatrick provide an overview of this position in Foucault's Law (London 2009), chs. 1, 2

105 Foucault, STP, 57.

106 Ibid., at 63.

107 Ewald, "Norms", 138 (quoting $\operatorname{HoS} 1,144$ ). 
part regulatory." 108 Moreover, although law might have juristic or constitutional priority over other instruments of governmentality in the sense of legitimating or authorising them, Foucault seems not to have regarded that as conferring any special significance upon it.

This view of law, as one manifestation of power among others, could be the source of the difficulty some jurists see in Foucault: he does not take law sufficiently seriously. Yet the assumption that he must take law seriously begs the question, since law's exact role in an account of power should, at the outset of inquiry, be an open question. It seems to have been open for Foucault and there is no definitive answer to it in his later work, save for that just given. Nor is that answer obviously unsatisfactory, since holding that law is one manifestation of power or governmentality among others is perfectly compatible with a recognition of law's importance in contemporary societies. It might be suggested that Foucault tells us nothing precise about law's importance, failing to specify where it ranks on a scale, but that seems silly. The topic of Foucault's latter work was power (and the subject), not law, and we cannot criticise him for failing to provide a detailed analysis of law: he either thought it insufficiently important or lacked the time to provide it. Neither possibility means Foucault's latter work lacks material or ideas which can inform our thinking about law: the processes of "normation" and normalisation have been used by Foucauldians to illuminate many aspects of modern law. ${ }^{109}$ The key Foucauldian claim about law in the argument offered here is that it plays significant and diverse roles, far beyond the exercise of a subtractive sovereign power, in the implementation and realisation of biopower and governmentality.

Will the death of law be a cause for regret? The existence of technologies that ensure regulatees comply with the law, often regardless of their agency, is surely a good thing. Golf carts or shopping trolleys that cannot be stolen, cars that cannot exceed the speed limit and contracts that cannot be breached, look like positive developments, a protection of or increase in human well-being. How can more of this kind of regulation, which deprives those so inclined of the opportunity to do bad things, be objectionable? Jurists have nevertheless objected to it on a number of grounds. The most common is that technological management seems prone to transgress the principles that inform the rule of law. ${ }^{110}$ Slightly less common are the objections that technological management undermines human dignity, on the one hand, and freedom, on the other, since it either treats human beings

108 Foucault, $\operatorname{HoS} 1144$.

109 See Tadros, Ewald and Martire, note 104 above, for examples.

110 Some instances: Brownsword, Law, Technology and Society, 18-19, ch. 5; Hildebrandt, "Law as Information", 22-30 and her "Law as Computation in the Era of Artificial Legal Intelligence: Speaking Law to the Power of Statistics" (2018) 68 U.T.L.J. 12, 34-35 (although the whole essay is really a meditation on the rule of law); F. Pasquale and G. Cashwell, "Prediction, Persuasion, and the Jurisprudence of Behaviourism" (2018) 68 U.T.L.J. 63 (a powerful critique of one instance of legal predictive machine learning (72-79) combined with a fairly glib invocation of at risk "core rule of law values" (67)). 
as objects or illegitimately limits their sphere of action. ${ }^{111} \mathrm{I}$ do not doubt the weight of some versions of these objections, but wish instead to highlight another worry additional to or possibly latent within them. It is this: if technological management is generalised as a means of regulation, then the space for human agency will contract and, as a result, agency may wither and die.

This sounds hyperbolic, yet its truth depends upon an undeniable claim about agency: it is best conceived as a performance dependent upon the fairly frequent exercise of a range of capacities and, of course, judgment. Agency is therefore what Charles Taylor terms an exercise-concept. ${ }^{112}$ Understood thus, it is exactly like its particular instances, such as playing the piano: something at which one can become better or worse and which requires practice. Practising implies the possibility of going wrong and making mistakes. Living a life is also, clearly, a matter of practice, an ongoing doing during which one can err. The possibility of error is what makes understanding possible, while actual errors often serve to make lives better. "I've learned from my mistakes" is a cliché among the mildly self-obsessed, alongside the "I'm a better person/parent/sibling/ friend/piano player now" trope. The truth in the cliché is that agency is a doing, a practice, and, if we need to practise it as often as golf or the piano, then the more opportunities we have to do it, the better. Envisaged as an East Coast regulatory form, law leaves as much room as possible for agency, while West Coast regulation is ambivalent on the issue. That ambivalence, when combined with technological management, can shrink the space for the doing of agency and thus undermine the capacities upon which agency depends.

Finally, why will law die before 2061? That year, as noted by Brownsword, will mark the centenary of the publication of H.L.A. Hart's The Concept of Law. ${ }^{113}$ That paean to rule regulation, an unselfconscious testament to the dominance of the East Coast regulatory paradigm, is losing intellectual purchase on our world. While Brownsword suggested that Hart's wisdom might be redundant by 2061, I think it will be otiose at least two decades before that. For the changes noted here, under the guise of technological management and its accompanying and burgeoning infrastructure of artificial intelligence and ubiquitous computing, are gathering speed. ${ }^{114}$ They are governmentality's "continuous regulatory and corrective mechanisms" and LAJ's death knell. ${ }^{115}$

\footnotetext{
111 See Brownsword, "Erewhon" (on dignity) and his Law, Technology and Society, 12-15 (on autonomy and liberty).

112 See ch. 8 of his Philosophy and the Human Sciences, 213. For the suggestion that medical judgement is similar, see Hildebrandt, "Law as Computation", 32-34 (on Zeb, a machine-learning diagnostic tool).

113 3rd ed. (Oxford 2012); see Brownsword, "2061", 1.

114 According to Moore's law (computer processing speeds double every 18 months).

115 For other possible futures, see Lucy, "Law School 2061", section III.
} 